\title{
IT in Education Organization: A Strategic Planning Approach
}

\section{Syahrul Fahmy, Abdul Razak Hamdan \& Aziz Deraman Universiti Kebangsaan Malaysia, Bangi, Malaysia}

\author{
sfahmy@taninet.com.my, arh@sunt.ftsm.ukm.my, ad@sunt.ftsm.ukm.my
}

\begin{abstract}
Information Technology (IT) has significant impacts to modern organizations especially in assisting daily operations and meeting business targets. Main contributions of IT to organizations are increased efficiency, effectiveness and competitiveness. Non-profit organizations can also benefit as much as for-profit organizations from IT. Education Organizations (EOs) for example, would benefit in terms of effective management of assets, improved communication channels, management of education system changes and systematic dissemination of academic materials. This paper proposes an IT Strategic Planning (ITSP) framework for EOs in order to plan and manage IT-related resources. The framework comprises of five phases namely Strategic Direction, Analysis, Strategy, Implementation and Evaluation. End result of this process would be the ITSP Manual, a detailed documentation of the organization's strategic direction, its environment and specific action plans to achieve business targets. This manual can be used in policy and decision-making activities.
\end{abstract}

Keywords: IT Strategic Planning, Education Organization, Framework, Decision-Making, Competitive Advantage.

\section{Introduction}

First generation of modern computers were introduced in the 1940s. ENIAC, UNIVAC-1 and IBM 650 to name a few, were the first general-purpose computers followed by the IBM 360 series in the 1960s. IBM uses integrated circuits as opposed to transistors, making ways for computers to be used in business organizations. In the 1970s, advances in microchip technology have led to the introduction of mini and microcomputers such as IBMPC/ AT, IBM PS/2 and IBM Valuepoint.

Since then, organization structure and working environment have never been the same. Information needs has changed significantly with the use of IT and computer-based systems (Rogerson \& Fidler 1994). Not only IT affects the organization's external factors such as clients, competitions, product and suppliers (Senn 1987) but internal factors as well for example information retrieval, communication channels and organizational structure as a whole (Bawden \& Blakeman 1990).

Non-profit organizations such as Education Organizations (EOs) are also affected by IT. EOs have to accommodate the educational possibilities of high-speed computing, instant access to electronic databases, the potential of electronic publishing and developing communication channels with international network

Material published as part of these proceedings, either on-line or in print, is copyrighted by Informing Science. Permission to make digital or paper copy of part or all of these works for personal or classroom use is granted without fee provided that the copies are not made or distributed for profit or commercial advantage AND that copies 1) bear this notice in full and 2) give the full citation on the first page. It is permissible to abstract these works so long as credit is given. To copy in all other cases or to republish or to post on a server or to redistribute to lists requires specific permission from the publisher at Pubtisher@unfomingseience.org of scholars (Breivik 1998).

The objective of this paper is to propose an IT strategic planning framework for EOs. The framework is based on the traditional strategic planning system (David 1997; Goodstein 1993) and the IT Strategic Planning Manual for Public Sector (Aziz et al. 
1997; 2000). The framework entails vital processes and steps that are involved in IT strategic planning.

\section{The Need for IT Strategic Planning for Education Organizations}

IT strategic planning or ITSP can be defined as 'Planning for the effective management of information in all forms - information systems and technology; manual and computerized systems; computer technology and telecommunications - which includes the organizational aspects of the management of IT throughout business' (Ward \& Griffiths 1996).

There are several reasons why EOs should engage in ITSP. First and foremost, ITSP promotes effective management of expensive and critical assets; improves communications channels; plans the flow of information and processes; allocates resources efficiently; and reduces total time and expenses of information system life cycle (Cassidy 1998).

Second, IT especially the Internet has changed the traditional education system significantly. Access to information is no longer restricted to time and space, thus promoting self-learning among students (Ellsworth 1994). IT affects various processes such as teaching and research while providing on-line information to external parties (scholarships, services provided, jobs), scheduling (lectures, exams, events) and registration.

Third, IT promotes electronic publishing of academic materials. According to Kirsop et al. (1996), for electronic publishing to be accepted by the international scientific community, the content should be accessible by a wide range of access rate and should cost less than the printed equivalent.

Finally, ITSP provides means for competitive advantage. IT is used by organizations to increase efficiency through innovation, communication and business network (Johennessen 1994). Not only IT promotes efficiency and effectiveness throughout an organization, it is equally important to the organization's success (Klouwenberg et al. 1995).

Clearly, IT has a tremendous impact to EOs in terms of improving communications, managing changes, disseminating academic materials and as means for competitive advantage. A structured planning system is needed to manage the profound impact of IT and IT-related resources. The system should support management decision-making activities by providing critical and timely information.

\section{Proposed It Strategic Planning Model for Education Organization}

The organization of EOs can be divided into two entities. First would be the faculties, institutes, centers, libraries and other institutions governed by EOs. Benefits of IT to this tangible entity can be monetarily assessed. Examples would be total student enrolment, number of on-line publications and total number of on-line database available at the library.

The second entity consists of students, academic staffs and other employees of EOs. Benefits of IT to this entity are intangible and cannot be easily determined in terms of dollars and cents. Examples would be the academic value of on-line materials, employee work efficiency and developed skill.

The ITSP process involves these two entities as they constitute the EO. Once the EO has set its target, information needs and requirements of these entities must be identified and acquired. Business target(s) of EOs differs from profit-based organizations. EOs are not required to be 'financially healthy' in order to be competitive in the industry. Therefore, EOs may opt to set their target according to technology.

There are four basic types of IT (Laudon et al. 1999) namely sensing, analyzing, display and communication technologies. Sensing technology involves devices that help gather raw data from the environment and translate them into machine-readable data. Examples of devices would be image scanners, sensors and digital gloves. 
Analyzing technology deals with physical hardware component of computers and appropriate software programs in order to change data into valuable information. Examples would be microcomputers, workstations, minicomputers and mainframes.

Display technology concerns devices and software programs in delivering information to human users by all means for example by sight and sound. Examples would be LCD screens, virtual reality display devices and talking computers.

Communication technology ties sensing, analyzing and display technologies together via specific communication channels. Examples are Local Area Network, cellular telephones and fax machines.

The conceptual model of ITSP for EOs is depicted in Figure 1.

ITSP aids the EO in setting its target; identifying information needs and requirements; developing and implementing strategies; and finally monitoring and evaluating the IT projects implementations. It demands responsibility and commitment from all involved. Influencing factors in the environment need to be identified and monitored. Changes need to be addressed quickly and systematically so that negative impact could be minimized if not eliminated.

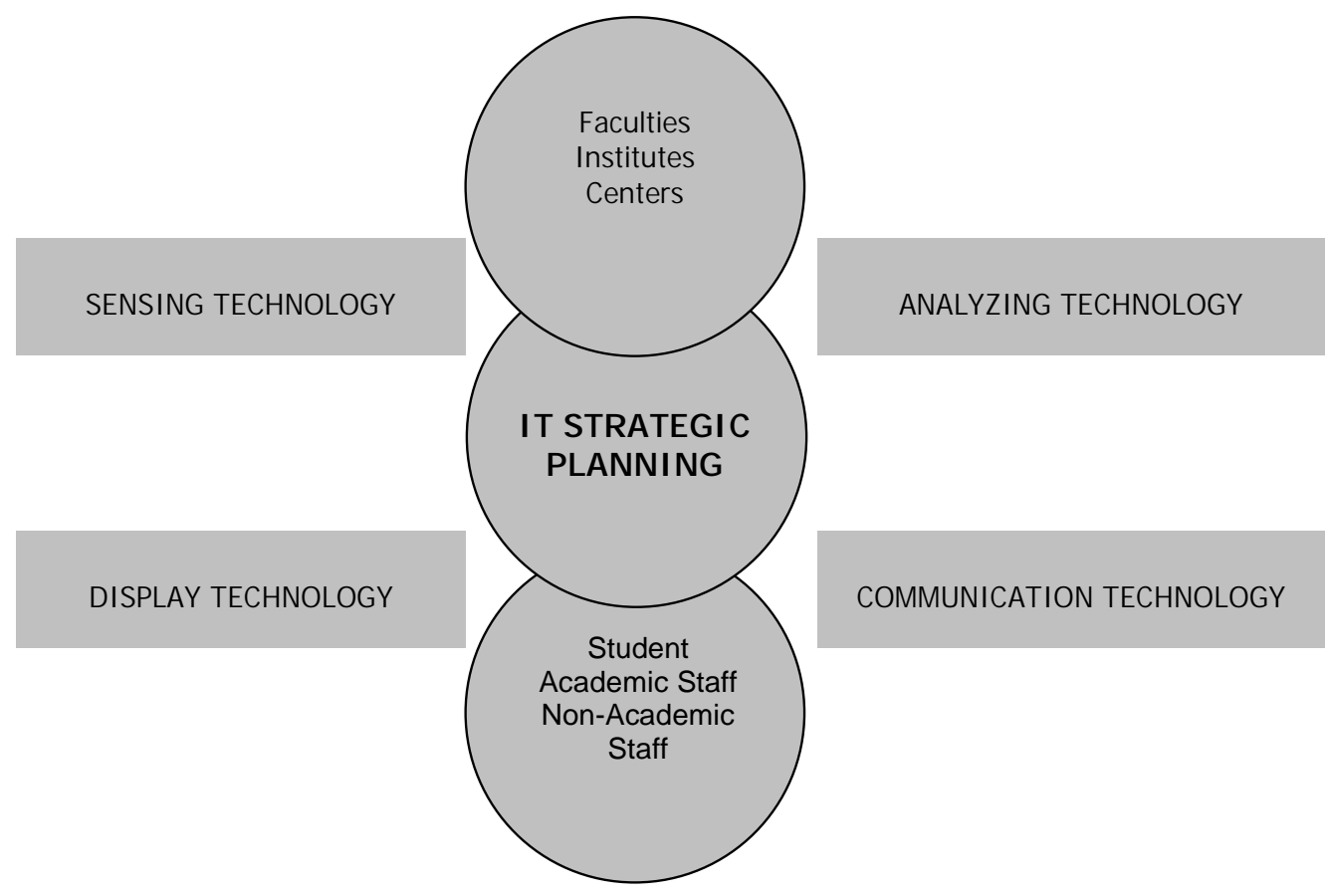

Figure 1:Conceptual Model of IT Strategic Planning for Education Organizations

\section{IT Strategic Planning Framework for Education Organization}

The ITSP framework for EOs is depicted in Figure 2. ITSP has five phases namely strategic direction, analysis, strategy, implementation and evaluation. The arrows represent data and information flow. ITSP is an ongoing process, indicated by the arrows running back and fourth, entering all phases of ITSP. Output of one phase is used in other phases mainly for decision-making purposes. End result of this process is the ITSP Manual, comprises of the organization's direction statements, SWOT analysis and strategy statements. 


\section{Strategic Direction}

The first phase of the ITSP process is setting strategic direction. This would mean evaluating and deciding which technology type (sensing, analyzing, display, communication) should the organization ventures into. The strategic direction is reflected in the organization's mission, goal and objective statements.

Mission is a clear and concise statement to represent the current or expected direction (Barry 1998, Drohan 1999, Luther 1995). Goal, on the other hand, is a concise and specific statement to represent the organization's current business operation. Objective is a specific action statement representing the approach to achieve organization's goals (Klouwenberg et al. 1995). It describes what the organization wishes to accomplish (Harrison 1995) and describes responsibility, monitoring methods and evaluation techniques that will be used (Kaufman 1992).

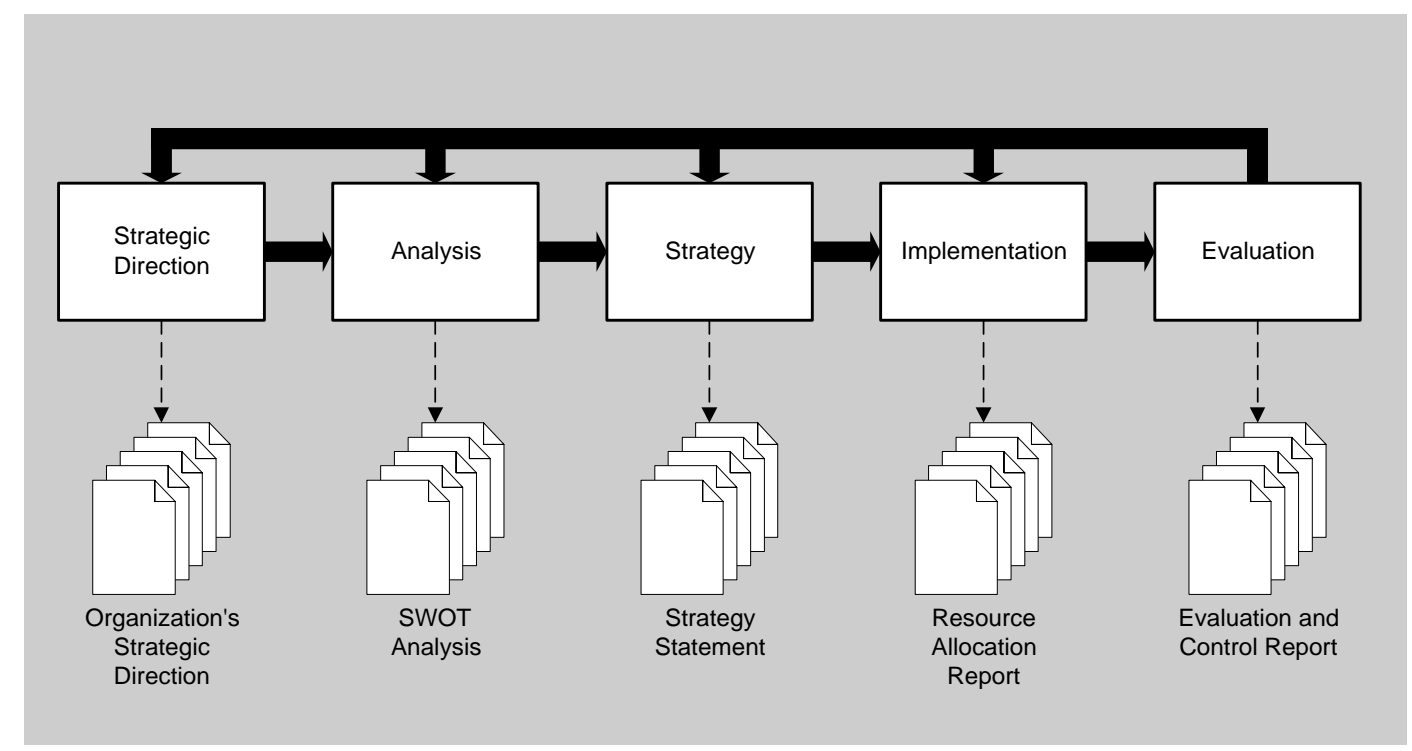

Figure 2: Framework for IT Strategic Planning

The result of this phase is a documentation of the organization's direction, stated in the form of mission, goal and objective statements. Examples from the Faculty of Technology and Information Sciences, UKM (http://WWW.ttsm.ukm.my):

Mission Statement: The Faculty of Technology and Information Sciences is determined to become the center of education, consultancy and point of reference in the field of technology and information sciences in accordance with the University's philosophy and mission.

Goal Statements: To produce graduates of high quality in technology and information sciences.

To become the center of research, consultancy and development in the field of technology and information sciences.

To disseminate information on technology and information sciences to the public.

To promote interaction and knowledge ties between experts in technology and information sciences with experts in other field.

To enhance the faculty's human resource development and infrastructure program. 


\section{Analysis}

The second phase in the ITSP process is analysis. Analysis is identifying and monitoring factors in the environment, both external and internal, which affect the overall operation of the organization. The main objective of this phase is to identify the strength, weakness, opportunity and threat (SWOT) factors of the organization.

General factors analyzed include economics, finance, globalization issues, organization (management, policy, resources), market, customers, competitors, politics, regulations and technology (Aziz et al. 2000, Drohan 1997, Harrison \& Pelletier 1998, Karake 1997, Phillips 1995, Proctor 1997, Thompson 1996).

Specific factors for EO include:

- Hardware and software.

- Network infrastructure.

- Information systems.

\section{Hardware and Software}

Hardware and software are the most important IT components. Hardware is the physical components or peripherals of a computer system. There are three categories of hardware: input device, storage device and output device. Examples are touch screen, MICR, OCR, voice data entry, magnetic tape, optical disk, Visual Display Unit (VDU), printers and voice output synthesizer.

Software is a set of instructions and procedures that controls the operation of a computer. There are two types of software: system and application. Examples are operating systems such as Windows2000 and Linux; utility programs; personal productivity tools such as word processing and spreadsheets; integrated software packages; and business application software such as accounting and project management.

Current hardware and system software should be analyzed while breakthroughs in IT technologies need to be assessed and adopted where appropriate. Obsolete systems would eventually produce less than expected output in terms of quality and quantity.

\section{Network Infrastructure}

Network infrastructure is a collection of inter-operational elements consisting of computer hardware, software and communication devices. IT network infrastructure includes transmission media such as phone lines and satellites; transmission controlling devices such routers and repeaters; and software.

Examples from the Multimedia Super Corridor (http://www.msc.com.my):

Supporting the MSC is a high-capacity, digital telecommunications infrastructure designed to the highest international standards in capacity, reliability, and pricing. This information network is part of an integrated logistics hub enabling rapid distribution of products along modern land, air, and sea links.

Key telecommunications network features that will link the MSC to regional and global centers include:

- A fiber-optic backbone with an unprecedented 2.5-10 gigabits per second capacity, which is more than enough network power to support virtual boardrooms, remote $\mathrm{CAD} / \mathrm{CAM}$ operations, and live multimedia internet broadcasting.

- High-capacity links to international centers to ensure that information, products, and services flow freely and quickly between MSC companies, their overseas partners, and export markets. 
IT in Education Organization

- Open standards, high-speed switching, and multiple protocols including ATM that brings power and flexibility to the development and implementation of multimedia applications.

- Best-in-class performance guarantees including installation of telephone services within 24 hours, ATM circuits within five days, and a 99.9 per cent service availability.

- Competitive telecommunications pricing including flat rate, low pricing for basic network services compared with other regional centers, and an open-entry policy for value-added network services to ensure the MSC maintains its competitive edge.

- Integration into the new transportation projects such as a dual "smart" highway and rapid transit rail system, linking the new MSC cities of Putrajaya and Cyberjaya with Kuala Lumpur and the Kuala Lumpur International Airport (KLIA).

\section{Information System}

Typical types of information systems include Office Automation System, Communication System, Transaction Processing System, Management and Executive Information System, Decision Support System, Execution System, Groupware System (Alter 1996), Financial Information System, Human Resource Information System and Marketing Information System (McLeod \& Schell 1999).

Information policy should also be reviewed and evaluated. The benefit of such policy include integration of all information activities, basis for objective and sound decision making, reduce if not eliminate resources waste, promote cooperation and make the organization more capable of responding to changes in the environment (Orna 1999).

Examples of information systems used in Universiti Kebangsaan Malaysia (http://www.ukm.my/ewarga ):

- Student Information System.

- Staff Information System.

- University Financial System.

- Staff Evaluation Information System.

- Research Management Center Information System.

- Internal Complaint System.

- Traffic Information System.

- e-Ticket.

The result of the analysis phase is a list of influential factors in the organization's environment.

\section{Strategy Formulation}

The third phase in the ITSP process is strategy formulation. Strategy is a specific action plan to achieve business targets - mission, goals and objectives. It entails resource allocation and time frame to attain objectives. Strategy should be formulated, evaluated and selected.

Strategy formulation is the activity of developing specific action plan to achieve the organization's objective. Strategy evaluation is the activity of prioritizing generated strategies. This is done to identify viable strategies in order to not waste valuable resources by implementing weak strategies. Strategy selection is selecting appropriate strategy that will be carried out, subject to resource restrictions. 
The result of this phase is a list of action plans to achieve the organization's objectives, goals and mission. Example from the National Information Technology Council (http://www.nitc.org.my):

- Establish cooperative/ collaborative arrangements on regional/ international basis to protect and enhance e-Sovereignty.

- Establish, monitor and upgrade defense and security systems against "cyber-threats".

- Formulate and implement computer modeling/ simulation courses to build local expertise.

- Expand Mobile Internet Units project to rural and sub-urban areas.

- Review and reformulate legislation/ rules/ regulations to facilitate e-Business and eCommerce.

- Review and reformulate Universal Services Obligation program.

- Plan and operate "ICT Community Chest" for funding e-Community pilot project at local level.

- Reengineer public services delivery systems.

\section{Implementation}

The fourth phase in the ITSP process is strategy implementation. Simply put, strategy implementation is the operation of selected strategy. Resources such as financial, human resource and technology should be allocated according to priority. The result of this phase is a report on resource allocation to strategies.

\section{Evaluation and Control}

The fifth and final phase in the ITSP process is evaluation and control. Evaluation is the process of monitoring strategy implementation to ensure it conforms to a predetermined set of standards. Evaluation is important to ascertain the implementation process runs smoothly (Beecroft 1999) and to monitor the effectiveness of selected strategies (Canary 1992). Control on the hand, is the corrective measure taken to ensure performance is in line with standards and goals are met within the expected time (Fenn 1997; Phillips 1995). The result of this phase is the progress report of strategy implementation.

The ITSP process does not end at the final phase. Information flows back to previous phases as input for decision-making activities. ITSP is an ongoing process since the EO has to address changes in the environment everyday while trying to achieve its target. Once the target is met, the organization might want to venture into another field of technology, thus spinning the wheel again.

This section has discussed the phases and steps in ITSP. Results from activities in every phase form the ITSP Manual, a descriptive document of the organization's operation. It clearly defines:

1. The strategic direction of EO.

2. Influential factors in the environment.

3. List of specific action plans to achieve the objectives, goals and mission.

4. Resource allocation and duration of strategies.

5. Evaluation and control report of strategy implementation. 


\section{Conclusion and Future Work}

This paper has proposed an IT strategic planning framework for education organizations. The framework has five phases namely strategic direction, analysis, strategy formulation, implementation and last but not least, evaluation and control.

This framework would assist EOs to set strategic direction; analyze the environment; formulate and implement strategies; and evaluate its implementation. It is an open framework and can be modified to meet the requirements of other organizations. The framework gives a better picture and clearer understanding of the ITSP process.

Further work and refinement to the framework is needed for better integration. For example, a list of external and internal factors by organization industry could be proposed. This would enable better analysis of the environment. Similarly, a computer-based system to generate, assess and propose business strategies could be developed. This would provide more practical alternatives to organizations. In addition, an evaluation technique could also be proposed to assess the progress of strategy implementation.

Finally, a computer-support system based on this framework can be proposed and developed. This system would support organizations in implementing ITSP. Organizations could fully grasp the idea of ITSP before applying it to the real world. It is hoped that EOs can benefit much from this framework. It is a powerful tool in planning and managing IT-related resources.

\section{References}

Altar, S. 1996. Information Systems. A Management Perspective. Menlo Park: Ca: The Benjamin/ Cummings Publishing Company, Inc.

Aziz Deraman, A. Razak Hamdan, Abdullah Mohd Zin, A. Rashid A.Rahim, Mohd Zamri Murah, Amna Abdurrahman, Wong Hon Wai \& Yusnita Roslan. 1997. IT Strategic Planning in the Public Sector. IRPA 04-02-02-0002 Project Report.

Aziz Deraman, A. Razak Hamdan, Abdullah Mohd Zin, Kasmiran Jumari, A. Rashid A. Rahim \& Mohd Zamri Murah. 2000. IT Strategic Planning: Standards and Guidelines for the Public Sector. Monograph. Universiti Kebangsaan Malaysia.

Barry, B.W. 1998. A Beginner's Guide To Strategic Planning. The Futurist. 32(3): 33-36.

Bawden, D. and Blakeman, K. IT 1990. Strategies For Information Management. London: Butterworths.

Beecroft, G.D. 1999. The Role Of Quality In Strategic Management. Management Decision. 37(6): 499-503.

Breivik, P. S. 1998. Student Learning in the Information Age. Phoenix, Ariz: Oryx Press.

Canary, H.W. 1992. Linking Strategic Plans With Budgets. Government Finance Review. 8(2): 21-24.

Cassidy, A. 1998. A Practical Guide to Information Systems Strategic Planning. Boca Raton, Fla:St. Lucie Press.

David, F.R. 1997. Strategic Management. New Jersey: Prentice Hall Inc.

Drohan, W. 1997. Principles Of Strategic Planning: A Step-By-Step Approach. Association Management. 49 (1): 85-87.

Drohan, W. 1999. Writing A Mission Statement. Association Management. 51(1): 117.

Ellsworth, J.H. 1994. Education on the Internet. Indianapolis, Ind: Sams Publishing.

Faculty of Technology and Information Sciences, UKM. 2002. (On-line). http://www.ttsm.ukm.my. (March 08, 2002).

Fenn, D. 1997. No More Business As Usual. Inc. 19(16): 114-115.

Feurer, R. \& Chararbaghi, K. 1995. Strategy Development: Past, Present And Future. Management Decision. 33(6): 11-21.

Goodstein, L.D. 1993. Applied Strategic Planning: A Comprehensive Guide. New York: McGraw-Hill.

Harrison, B.J. 1995. Should Your Organization Invest In Strategic Planning? Fund Raising Management. 26(6): 14-17.

Harrison, E.F. dan Pelletier, M.A. 1998. Foundations Of Strategic Decision Effectiveness. Management Decision. 36(3): 147159. 
Johennessen. J. 1994. Information Technology And Innovation: Identifying Critical Innovation Factors. Information Management \& Computer Security. 2(2): 6-9.

Karake, Z.A. 1997. Managing Information Resources and Environmental Turbulance. Information Management \& Computer Security. 5(3): 93-99.

Kaufman, R. 1992. 6 Steps To Strategic Success. Training \& Development. 46(5): 107-112.

Kirsop, B.E., Edwards, A. and Souza, S. 1996. On-line Electronic Publishing: Developing for the Electronic Reader. The Information Revolution Impact on Science and Technology. Dubois, J.E. and Gershon, N. (eds.). Berlin Springer-Verlag.

Klouwenberg, M.K.; Koot, W.J.D. dan van Schaik, J.A.M. 1995. Establishing Business Strategy With Information Technology. Information Management \& Computer Security. 3(5): 8-20.

Laudon, K.C., Traver, C.G. and Laudon, J.P. 1999. Information Technology Concepts and Issues. Danvers, Mass: Boyd \& Fraser Publishing Company.

Luther, D.B. 1995. Put Strategic Planning To Work. Association Management. 47(1): 73-77.

McLeod, R. \& Schell, G. 1999. Management Information Systems $\left(8^{\text {th }}\right.$ ed). New Jersey: Prentice Hall Inc.

Multimedia Super Corridor. 2002. (On-line). tttp://www.msc.com.my, (March 08, 2002).

National Information Technology Council. 2002. (On-line). http://www.nitc.org.my (March 08, 2002).

Orna, E. 1999. Practical Information Policies. Aldershot: Gower.

Phillips, R. 1995. A 6-Step Plan For Magazine Executives: How To Bridge The Gap Between Management And Creativity. Folio: the Magazine for Magazine Management. 23(19): 242-243.

Proctor, T. 1997. Establishing A Strategic Direction: A Review. Management Decision. 35(2): 143-154.

Rogerson, S. \& Fidler, C. 1994. Strategic Information Systems Planning: Its Adoption and Use. Information Management \& Computer Security. 2(1): 12-17.

Sanderson, S.M. 1998. New Approaches To Strategy: New Ways of Thinking For The Millennium. Management Decision. 36(1): 9-13.

Senn, J.A. 1987. Information Systems In Management. Belmont: Wadsworth Publishing Co.

Thompson, J.L. 1996. Strategic Effectiveness and Success: The Learning Challenge. Management Decision. 34(7): 14-22.

Universiti Kebangsaan Malaysia. 2002. (On-line). nte:/www.ukm.my. (March 08, 2002).

Ward, J. \& Griffiths, P. 1996. Strategic Planning for Information Systems. Chichester: John Wiley \& Sons.

\section{Biography}

Syahrul Fahmy is a Ph.D. candidate at the Faculty of Technology and Information Sciences, Universiti Kebangsaan Malaysia. His research interest includes IT strategic planning, software quality/ certification and IT security.

A Razak Hamdan (Ph.D.) is a professor in the Department of System Science and Management, Faculty of Information Science and Technology at Universiti Kebangsaan Malaysia,Bangi, Malaysia. His research interest includes inteligent systems, IT strategic planning, and IT management. He received a $\mathrm{PhD}$ from the University of Loughborough, UK in 1987

Prof. Aziz Deraman (PhD) is a professor in the Department of Computer Science, Faculty of Information Science and Technology at Universiti Kebangsaan Malaysia, Bangi, Malaysia. He is also the dean of Faculty of Information Science and Technology. His research interest includes software management, software quality, and IT strategic planning. He received a PhD from the University of Manchester Institute of Technology,UK in 1992 